\section{Celery Yield Responds to Phosphorus Rate But Not Phosphorus Placement on Histosols}

\author{
L. Espinoza, C.A. Sanchez, and T.J. Schueneman \\ University of Florida, Institute of Food and Agricultural Sciences, Everglades \\ Research and Education Center, P.O. Box 8003, Belle Glade, FL 33430
}

Additional index words. Apium graveolens, plant analysis, soil testing

\begin{abstract}
Four field experiments were conducted during two production seasons to evaluate soil-test $\mathbf{P}$ fertilizer recommendations for celery (Apium graveolens var. dulce) produced on Histosols, which often are linked hydrologically to environmentally sensitive wetlands, and to evaluate band placement as a strategy for improving $P$ fertilizer-use efficiency in celery in such areas. Phosphorus was applied (broadcast or banded) at 0,50 , 100,150 , and $200 \mathrm{~kg} P / \mathrm{ha}$. Broadcast $P$ was surface-applied and disked into the soil $\approx 15 \mathrm{~cm}$ deep 1 day before planting. Banded $P$ was applied $5 \mathrm{~cm}$ below the soil surface and $5 \mathrm{~cm}$ to the side of each celery row. Total above-ground mass, marketable trimmed yield of celery, and yield of the larger grade sizes increased with $P$ rate in all experiments. Band $P$ placement was not a viable strategy for improving $P$ fertilizer-use efficiency for celery. However, our results indicate that previous soil-test-based $P$ fertilizer recommendations for celery were too high for the cultivars grown currently, and improved $P$ fertilizer-use efficiency can be obtained with revised soil-test calibrations.
\end{abstract}

Large amounts of the celery marketed in the United States are produced on Histosols in Florida, Michigan, Ohio, and New York (Lucas, 1982). Celery also is produced on Histosols in Canada (Lucas, 1982). Because Histosols used for crop production often are linked hydrologically to environmentally sensitive wetlands, it is imperative that management strategies be sought that improve the efficiency of $P$ fertilization. Concern has been expressed that $\mathrm{P}$-enriched drainage waters in southern Florida may be exerting a negative impact on the ecology of Lake Okeechobee and the Everglades Conservation Area National Park ecosystems (Fredrico et al., 1981; Swift and Nicholas, 1987). Similar concerns have been expressed in other areas where Histosols are used extensively for crop production (Duxbury and Peverely, 1978; Longabucco and Rafferty, 1989; Miller, 1979). In southern Florida, vegetables generally are fertilized more heavily than agronomic crops such as sugarcane (Saccharum spp.) because of rigid produce quality standards enforced by the market. Additionally, water quality monitoring data seem to suggest that $\mathrm{P}$ loads are higher from vegetable fields than from sugarcane fields (Izuno et al., 1991). Improved fertilizer management has been suggested as a

Received for publication 4 Jan. 1993. Accepted for publication 14 June 1993. University of Florida Agricultural Experiment Station Journal series no. $\mathrm{R}-02823$. This research was funded in part by the SouthernFloridaSoilTestAdvisoryBoard. The cost of publishing this paper was defrayed in part by the paymentof page charges. Under postal regulations, this paper therefore must be hereby marked advertisement solely to indicate this fact.

'To whom reprint requests should be addressed. Present address: Yuma Agricultural Center. 6425 W. 8th St., Yuma, AZ 85364. means of controlling $\mathrm{P}$ loading of drainage waters from Histosols (Cogger and Duxbury, 1984; Izuno et al., 1991) and is an integral part of the legal agreement made to reduce the threat of agriculture to southern Florida wetlands (U.S. District Court, 199 1). Strategies for reducing $\mathrm{P}$ losses from Histosols in the Everglades Agricultural Area (EAA) focus on lowering $\mathrm{P}$ fertilization rates by improved soil-test calibrations and on improving fertilizer placement.

Phosphorus fertilizer recommendations for celery produced on Histosols are based largely on soil-test calibration experiments conducted 40 years ago (Forsee, 1950). Most of these studies were conducted with golden-type celery cultivars, which respond differently to nutrients than the green-type cultivars currently grown (Burdine and Guzman, 1969). Recent work with green-type celery cultivars suggests that $\mathrm{P}$ fertilizer recommendations may be too high (Beverly, 1984; Sanchez et al., 1990). However, additional studies on soils with low residual $\mathrm{P}$ were needed.

Improved fertilizer efficiency from band fertilizer placement has been recognized for some time (Davis et al., 1956; Locascio et al., 1960). However, response to band placement is variable among vegetables (Nettles and Hulbert, 1966). Recently, Sanchez et al. (1990) reported that the amount of $\mathrm{P}$ required for lettuce (Lactuca sativa L.) production could

Table 1. Planting and harvest dates for celery, weather conditions, and selected soil properties for each experiment.

\begin{tabular}{lcccccc}
\hline \hline & $\begin{array}{c}\text { Planting } \\
\text { date }\end{array}$ & $\begin{array}{c}\text { Harvest } \\
\text { date }\end{array}$ & $\begin{array}{c}\text { Mean } \\
\text { temp } \\
\left({ }^{\circ} \mathrm{C}\right)\end{array}$ & $\begin{array}{c}\text { Rainfall } \\
(\mathrm{cm})\end{array}$ & $\begin{array}{c}\text { Soil pH } \\
\text { Expt. }\end{array}$ & $\begin{array}{c}\text { Soil } \\
\text { test P } \\
\left(\mathrm{g}^{\bullet} \mathrm{m}^{-3}\right)\end{array}$ \\
\hline Winter 1989 & 28 Dec. 1989 & 26 Apr. 1990 & 21 & 32.4 & 7.1 & 4.4 \\
Spring 1990 & 18 Mar. 1990 & 13 June 1990 & 23 & 30.0 & 7.5 & 3.1 \\
Winter 1990 & 20 Dec. 1990 & 4 Apr. 1991 & 20 & 34.6 & 7.2 & 4.1 \\
Spring 1991 & 20 Feb. 1991 & 29 May 1991 & 23 & 32.7 & 7.8 & 1.6 \\
\hline
\end{tabular}
which are based on the number of stalks $(1.5$ be reduced by $66 \%$ when $\mathrm{P}$ fertilizer was banded instead of broadcast. For sweet corn (Zea mays L.), however, the relative efficiency of banded to broadcast $\mathrm{P}$ fertilization was not constant but ranged from $1: 1$ to $3: 1$, depending on soil-test $\mathrm{P}$ level (Sanchez et al., 199 1). We have no information on how celery responds to band $\mathrm{P}$ placement.

Four field studies were conducted between 1989 and 1991 to evaluate soil-test P fertilizer recommendations for celery produced on Histosols in Florida and to evaluate band $\mathrm{P}$ placement as a strategy for improving fertilizer-use efficiency in celery. All experiments were conducted on a soil mapped as Pahokee muck (euic, hyperthermic, Typic Medisaprist). The planting dates, harvest dates, and selected soil properties are shown in Table 1 .

The $P$ rates were $0,50,100,150$, and 200 $\mathrm{kg} \mathrm{P} / \mathrm{ha}$ as triple superphosphate in all experiments. In the winter 1989 experiment, only broadcast application was used; in all other experiments, broadcast and band application were evaluated. Broadcast $\mathrm{P}$ was surface-applied and disked into the soil $\approx 15 \mathrm{~cm}$ deep 1 day before planting. Banded $\mathrm{P}$ was applied 5 $\mathrm{cm}$ below the soil surface and $5 \mathrm{~cm}$ to the side of each celery row immediately after transplanting. Plots measured $9.14 \times 9.14 \mathrm{~m}$ and were arranged in a randomized complete-block design with five replications for each treatment. However, during the spring 1991 experiment, only three replications were harvested because of a disease infestation unrelated to treatments that compromised the results from the unharvested plots.

Potassium was applied based on a preplant soil test, and $\mathrm{Zn}, \mathrm{Mn}$, and B were applied at 9 , 9, and $2 \mathrm{~kg} \cdot \mathrm{ha}^{-1}$, respectively (Sanchez, 1990). Nitrogen was applied at $50 \mathrm{~kg} \cdot \mathrm{ha}^{-1}$ in two sidedressings $\approx 6$ and 8 weeks after transplanting for a total application rate of $100 \mathrm{~kg} \mathrm{~N} / \mathrm{ha}$. Water was supplied using subsurface irrigation from field ditches by maintaining a water table 45 to $65 \mathrm{~cm}$ below the soil surface (Snyder et al., 1978).

'June Belle' celery was seeded and transplanted with an in-row spacing of $22 \mathrm{~cm}$ and a between-row spacing of $61 \mathrm{~cm}$ to give an approximate population of 7.5 plants $/ \mathrm{m}$. Celery was harvested from $6.1 \mathrm{-m}$ sections of two rows in each plot. After recording the untrimmed weights, celery was trimmed and separated into marketable size categories, $2,3,4$, or 5 dozen) required to fill a standard box. The number and weight of each marketable size category was recorded for each plot.

Outer petioles from each of 15 plants were collected in each plot for mineral analysis midseason. All tissue samples collected were 
Table 2. Total marketable yield and marketable yield of large grade sizes ( $\leq 2.5$ dozen stalks per box) as affected by $\mathrm{P}$ rate (PR) and placement (PP).

\begin{tabular}{|c|c|c|c|c|c|c|c|c|c|c|c|c|c|}
\hline \multirow[b]{2}{*}{ Variable } & \multicolumn{5}{|c|}{ Total marketable yield $\left(\mathrm{t} \cdot \mathrm{ha}^{-1}\right)$} & \multicolumn{8}{|c|}{ Marketable yield, large sizes $\left(\mathrm{t} \cdot \mathrm{ha}^{-1}\right)$} \\
\hline & Winter 1989 & Spring 1990 & Winter 1991 & Spring 1991 & $\begin{array}{c}\text { Overall }^{2} \\
\text { mean }\end{array}$ & Winter & 1989 & Spring & 1990 & Winter & 1991 & Spring 1991 & $\begin{array}{c}\text { Overall }^{2} \\
\text { mean }\end{array}$ \\
\hline \multicolumn{14}{|l|}{$\overline{\mathrm{PR}}$} \\
\hline \multicolumn{14}{|l|}{$\left(\mathrm{kg}^{\prime} \mathrm{ha}^{-1}\right)$} \\
\hline 0 & 58.9 & 31.9 & 46.2 & 43.7 & 45.2 & 40.7 & & 1. & 4 & .17 & & 26.6 & 21.6 \\
\hline 50 & 71.5 & 42.9 & 62.6 & 56.8 & 58.5 & 63.3 & & 8. & 4 & 39 & .0 & 49.9 & 40.1 \\
\hline 100 & 66.4 & 42.1 & 59.1 & 59.1 & 56.7 & 53.0 & & 11. & & 31 & 0 & 51.7 & 36.7 \\
\hline 150 & 62.1 & 45.1 & 65.0 & 59.9 & 58.0 & 52.9 & & 15 . & & 40 & 6 & 53.8 & 40.8 \\
\hline 200 & 70.1 & 45.0 & 63.1 & 61.2 & 59.8 & 53.0 & & 13. & & 39 & & 53.8 & 39.9 \\
\hline \multicolumn{14}{|l|}{$\mathbf{P P}^{\mathbf{y}}$} \\
\hline Broadcast & --- & 45.7 & 64.3 & 58.0 & 56.0 & --- & & 15 . & & 39 & 4 & 51.6 & 35.3 \\
\hline \multirow{2}{*}{\multicolumn{14}{|c|}{ Significance }} \\
\hline & & & & & & & & & & & & & \\
\hline PR & $L^{* *} Q^{*}$ & $\mathrm{~L}^{* *}$ & $\mathrm{~L}^{* *} \mathrm{Q}^{*}$ & $\mathrm{~L}^{* *} \mathrm{Q}^{* *}$ & $\mathrm{~L}^{* *} \mathrm{Q}^{* *}$ & NS & & $\mathrm{L}^{*}$ & & $\mathbf{L}$ & $*$ & $L^{* *} Q^{* *}$ & $\mathrm{~L}^{* *} \mathrm{Q}^{* *}$ \\
\hline $\mathrm{PP}^{\mathrm{y}}$ & $\cdots$ & NS & NS & ** & NS & --- & & N: & & $\mathrm{N}$ & $s$ & NS & NS \\
\hline $\mathrm{PR} \times \mathrm{PP}$ & --- & * & NS & NS & NS & --- & & $*$ & & $\mathrm{~N}$ & s & NS & NS \\
\hline
\end{tabular}

${ }^{2}$ Main effect means and associated statistics for $P$ rate include data from four seasons, while means and associated statistics for $P$ placement are from three seasons. 'Control not included in placement comparisons.

$* * *$ Significant linear $(\mathrm{L})$ or quadratic $(\mathrm{Q})$ response at $P \leq 0.05$ and 0.01 , respectively

dried at $65 \mathrm{C}$ for $72 \mathrm{~h}$ and ground for elemental analysis. After wet ashing with $\mathrm{H}_{2} \mathrm{SO}_{4} / \mathrm{H}_{2} \mathrm{O}_{2}$ (Wolf, 1982), P was determined colorimetrically.

Soil samples were collected before fertilization and planting, and at midseason. Waterextractable $\mathrm{P}$ was determined using methods described by Sanchez (1990).

Data were subjected to regression analysis using SAS-GLM and SAS-NLIN procedures (SAS, 1985). Critical soil and tissue test levels were calculated by solving the Mitscherlich equation (Ware et al., 1982) at $97 \%$ relative yield.

Length of growing period for celery produced during the four seasons ranged from 87 to 119 days. Rainfall amounts were similar during each of the four experiments (Table 1). Although the average seasonal mean temperature was also similar during all experiments, celery was grown under conditions of decreasing temperatures in the winter seasons vs. conditions of increasing temperatures in the spring seasons. Initial soil tests showed that the soils used in all experiments were low in available P (Table 1).

The pooled analysis of variance for the four seasons shows highly significant $(P \geq$ 0.01 ) seasonal effects for total mass produced and marketable yield (data not shown). Total above-ground mass averaged $105 \mathrm{t} \cdot \mathrm{ha}^{-1}$ in Winter 1989, 66.7 in Spring 1990, 90.2 in Winter 1990, and $91.3 \mathrm{t} \cdot \mathrm{ha}^{-1}$ in Spring 1991. Trimmed weights (marketable yield) averaged 65.8, 42.4, 60.6, and 57.5 tha ${ }^{-1}$ during Winter 1989, Spring 1990, Winter 1990, and Spring 1991, respectively. Yield potential of celery was definitely lower in the spring, particularly in 1990 , probably due to high temperatures during the final weeks of the growing period. Celery achieves $\approx 70 \%$ of its growth during the last 2 or 3 weeks before harvest (Zink, 1963), and temperatures during this period exceeded the optimum for celery and probably limited yields.

Total above-ground mass, marketable yield, and yield of the larger grade sizes (sizes 2.5 or larger, which generally have a higher market value) generally increased with $\mathrm{P}$ rate (Table
2). The pooled analysis of the three experiments where placement was evaluated showed no significant effect of $\mathrm{P}$ placement (Table 2). Overall, yields for broadcast $P$ placement averaged 56.0 tha $\mathrm{a}^{-1}$, while yields for band $\mathrm{P}$ placement averaged $54.3 \mathrm{t} \cdot \mathrm{ha}^{-1}$. There were trends within individual experiments for band placement to increase and decrease yields relative to broadcast application (Table 2). However, because the differences in yield were inconsistent and the effects of band placement sometimes negative, we must conclude that band $\mathrm{P}$ fertilizer placement is not a viable strategy for improving $\mathrm{P}$ fertilizer-use efficiency for celery. These results were surprising because band placement has been identified as a viable strategy for improving $P$ fertilizer-use efficiency for other vegetables produced on Histosols (Davis et al., 1956; Sanchez et al., 1990, 1991). In southern Florida, celery transplants are grown an average of 90 days in seedbeds, after which they are transplanted to the field where an additional 90 days generally are required to reach maturity (Guzman et al., 1973). Furthermore, an inspection of celery fields near maturity showed a dense proliferation of roots throughout the upper $20 \mathrm{~cm}$ of soil. Possibly, because of the long growing season and aggressive root system, banding offers no advantages in fertilizer-use efficiency for celery. These data for celery and those of previous studies with other vegetables showing positive responses to band placement (Sanchez et al., 1990, 1991) underscore the conclusion of Nettles and Hulbert (1966) that effectiveness of various placement methods must be evaluated for the various vegetables individually.

Since the yield response to $\mathrm{P}$ rate was significant, yield and soil-test data were used either to verify or modify current $P$ soil-test calibration data. The soil-test calibration approach used on Histosols in southern Florida is based on the double calibration approach described by Sanchez (1990). First, a relationship between relative yield as a function of extractable nutrient is used to calculate a critical soil test $\mathrm{P}$ level. A recommendation to apply fertilizer is made only when a soil sample tests below the critical level. The amount of nutrient recommended depends on the calibration ratio for a given soil, which is the relationship between the change in soil-test nutrient level to the amount of applied nutrient.

The relationship between soil-test $\mathrm{P}$ and relative yield on the broadcast treatments across all experiments was used to calculate a critical soil-test $P$ value. The calculated critical soil-test $P$ level was $9 \mathrm{~g} \cdot \mathrm{m}^{-3}$ using total marketable yield and $12 \mathrm{~g} \cdot \mathrm{m}^{-3}$ using yield of the larger grade sizes (Figs. 1 and 2). Since maximization of large grade sizes is of economic importance, the use of the latter value is probably preferable. Even this estimate is lower than the $18 \mathrm{~g} \cdot \mathrm{m}^{-3}$ currently used. Using the calibration ratio of $13.4 \mathrm{~kg} \mathrm{P} /$ ha per gram of $\mathrm{P}$ per meter reported by Sanchez et al. (1990) for this soil, an appreciable reduction in $\mathrm{P}$ fertilizer recommendations could be achieved (Table 3 ). For example, if a sample tests $4 \mathrm{~g} \cdot \mathrm{m}^{-3}$, we would recommend $190 \mathrm{~kg} \mathrm{P} / \mathrm{ha}$ using the current critical level, whereas we would recommend only $110 \mathrm{~kg} \mathrm{P} / \mathrm{ha}$ using the proposed critical level. These results are consistent with recent conjecture based on preliminary studies (Beverly, 1984; Sanchez et al., 1989) that P fertilizer recommendations for celery produced on Florida Histosols could be reduced substantially with no negative impact on crop yield and quality.

Previous workers have proposed the use of

Table 3. A comparison of $\mathrm{P}$ fertilizer recommendations, across various preplant soil-test values using the current and proposed critical level for celery.

\begin{tabular}{|c|c|c|}
\hline \multirow{2}{*}{$\begin{array}{l}\text { Soil-test } \\
\text { index level } \\
\left(\mathrm{g} \cdot \mathrm{m}^{-3}\right)\end{array}$} & \multicolumn{2}{|c|}{$\begin{array}{l}\text { Fertilizer recommendation } \\
(\mathrm{kg} \mathrm{P} / \mathrm{ha})\end{array}$} \\
\hline & Current & Proposed \\
\hline 2 & 210 & 130 \\
\hline 4 & 190 & 110 \\
\hline 6 & 160 & 80 \\
\hline 8 & 130 & 50 \\
\hline 10 & 110 & 30 \\
\hline 12 & 80 & 0 \\
\hline 14 & 50 & 0 \\
\hline 16 & 30 & o \\
\hline 18 & 0 & 0 \\
\hline
\end{tabular}




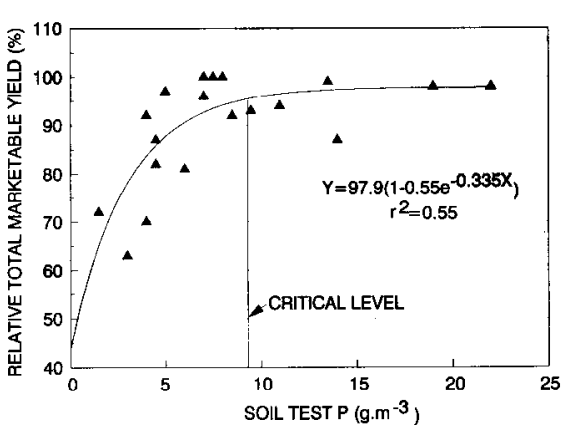

Fig. 1. Relationship between relative total marketableceleryyield and soil-test $\mathrm{P}$ across four field experiments.

a celery petiole tissue test as a nutritional diagnostic tool (Forsee, 1950). Although there were significant trends for the $\mathrm{P}$ concentration of petioles to increase with $\mathrm{P}$ fertilization rate, the data were variable and the relationship was generally poor (Fig. 3). The calculated critical value of $0.46 \%$ is within the range of values proposed previously (Beverly, 1984; Sanchez et al., 1990). However, because of the variability in petiole $\mathrm{P}$ concentration observed in these studies, additional work is needed to explore alternatives such as leaf tissue test or sap tests as indicators of $\mathrm{P}$ deficiency.

In conclusion, band $\mathrm{P}$ placement was not a viable strategy for improving $\mathrm{P}$ fertilizer-use efficiency for celery. However, our results indicate that previous soil-test-based $\mathrm{P}$ fertilizer recommendations for celery were too high, and improved $\mathrm{P}$ fertilizer-use efficiency can be obtained with revised soil-test calibrations.

\section{Literature Cited}

Beverly, R.B. 1984. Nutritional survey of the Everglades vegetable industry.Proc.Fla. State Hort. Soc.97:201-205.

Burdine, H.W. and V.L. Guzman. 1969. Celery cultivar response to $\mathrm{pH}$ adjustment on Everglades organic soils. J. Amer. Soc. Hort. Sci. 94:520-523.

Cogger, C. and J.M. Duxbury. 1984. Factors affecting P losses from cultivated organic soils. J. Environ. Qua]. 13:111-114.

Davis, J.F., W.C. Hulbert, C.M. Hansen, and L.N. Shephard. 1956. The effects of fertilizer placementontheyieldof onion and spinach grown on organic soils. Mich. Qual. Bul. 39:25-35.

Duxbury, J.M. and J.H. Peverely. 1978. Nitrogen and phosphorus losses from organic soils. J. Environ. Qual. 7:566-570.

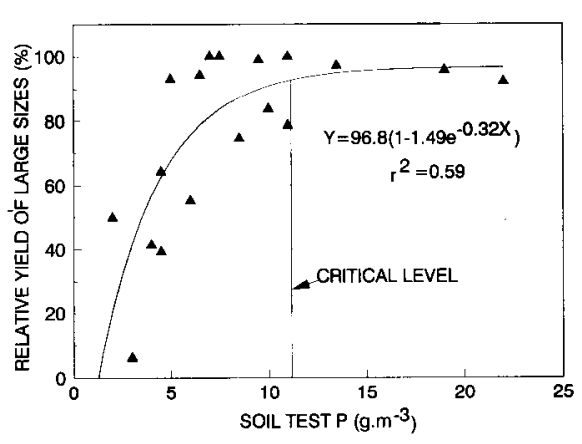

Fig. 2. Relationshipbetweenrelative yield of largegrade celery sizes and soil-test $\mathrm{P}$ across four fieldexperiments.

Forsee, W.T., Jr. 1950. The place of soil and tissue testinginevaluating fertility levels under Everglades conditions. Soil Sci. Soc. Amer. Proc. 15:297-299.

Fredrico, A.C., F.E. Davis, K.G. Diskson, and C.R Kratzer. 1981. Lake Okeechobee water quality studies and eutrophication assessment. South FloridaWaterManagementDistrictTech. Publ. 812. West Palm Beach, Fla.

Guzman, V.L., H.W. Bordine, E.D. Harris, J.R. Orsenigo, R.K. Showalter, P.L. Thayer, J.A. Winchester, E.A. Wolf, R.D. Berger, W.G. Genung, and T.Z. Zitter. 1973. Celery production on organic soils of south Florida. Univ. of Florida Agr. Expt. Sta. Bul. 757.

Izuno,F.T.,C.A.Sanchez,F.J. Coale, A.B. Bottcher, and D.B. Jones. 1991. Phosphorus concentrations in drainage water in the Everglades Agricultural Area. J. Environ. Qual. 20:608-619.

Locascio,S.J.,G.F. Warren, andG.E. Wilcox. 1960. The effect of phosphorus placement on uptake of phosphorus and growth of direct seeded tomatoes. Proc. Amer. Soc. Hort. Sci. 76:503514.

Longabucco, P. and M.R. Rafferty. 1989. Delivery ofnonpoint-sourcephosphorus from cultivated mucklands to Lake Ontario. J. Environ. Qual. 18:157-163.

Lucas,R.E.1982.Organicsoils (Histosols): Formation, distribution, physicalandchemicalproperties and management for crop production. Res. Rpt.435. Michigan State Univ. Press, East Lansing.

Miller, M.H. 1979. Contribution of nitrogen and phosphorus to subsurface drainage water from intensivelycroppedmineraland organic soils in Ontario. J. Environ. Qual. 8:42-48.

Nettles, V.F. and W.C. Hulbert. 1966. Effect of placementand levels of fertilizer on the yield of vegetables. Proc. Fla. State Hort. Soc. 79: 185191.



Fig. 3. Relationship between relative total marketable celery yield and petiole $\mathrm{P}$ across four field experiments.

Sanchez, C.A. 1990. Soil-testing and fertilizer recommendationsforcropproduction on Histosols in Florida. Univ. of Florida Agr. Expt. Sta. Bul. 876 .

Sanchez, C.A., H.W. Burdine, and V.L. Guzman. 1989. Soil-testing and plant analysis as guides for the fertilization of celery on Histosols. Soil Crop Sci. Soc. Fla. Proc. 49:69-72.

Sanchez, C. A., P.S. Porter, and M.F. Ulloa. 1991 Relative efficiency of broadcast and banded phosphorusforsweetcornproducedonHistosols. Soil Sci. Soc. Amer. J. 55:871-875.

Sanchez, C. A., S. Swanson, and P.S. Porter. 1990. BandingPtoimprovefertilizer use efficiency of lettuce. J. Amer. Soc. Hort. Sci. 115:581-584.

SAS. 1985. SAS users guide: Statistics, version 5 edition. SAS Institute, Inc., Cary, N.C.

Snyder, G. H., H.W. Burdine, J.R. Crockett, G.J. Gascho,D.S.Harrison,G. Kidder, J.W. Mishoe, D.L. Myhre, F.M. Pate, and S.F. Shih. 1978. Water table management for organic soil conservation and crop production in the Florida Everglades.Univ.ofFloridaExpt. Sta. Bul. 801.

Swift, D.R. and R.B. Nicholas. 1987. Periphyton and water quality relationships in the Everglades Conservation Areas. South Florida Water Management District Tech. Rpt. 87-2.

U.S.DistrictCourt.1991. Settlement agreement for case no. 88. 1886 CIV HOELLER. Southern Districtof Florida, Miami.

Ware, G.O., K. Ohiki, and L.C. Moon. 1982. The Mitscherlich growth response model for determiningcriticalnutrientdeficiencylevels.Agron. J. 74:88-91.

Wolf, B. 1982. A comprehensive system of leaf analysisandits use for diagnosing crop nutrient status.Commun. Soil Sci. PlantAnal.13:10351059.

Zink, F.W. 1963. Rate of growth and nutrient absorption of celery. Proc. Amer. Soc. Hort. Sci. 82:351-357. 